\title{
Figures of Migration: Intertextuality in Michelangelo's Night
}

Peter Gillgren

\begin{abstract}
Migration is a central feature of contemporary culture, bringing to our attention-among other things-certain problematic aspects of the concept intermediality. It may be asked if the concept is at all relevant in relation to such cultural phenomena. Below, it is argued that a return to Julia Kristeva's original concept of intertextuality could be the way forward. Discussing the example of Michelangelo's sculpture Night, it is argued that the specific work must be interrelated not only to the multimedia context of the Medici chapel but also to political and personal experiences of migration in the artist's own time and cultural sphere. Such perspectives, however, demand the consideration of psychological and political contexts that are commonly absent in intermedia studies. The Kristevian concept of intertextuality, on the other hand, allows for intermedia phenomena to take place in relation to the full complexities of art, life, and culture.
\end{abstract}

\section{Cultures of Migration}

"If we think of culture today," says Mieke Bal, "it is impossible not to think of migration." There is an analogy to be made here, she continues, "between the movement of people and the movement of images, a double movement through spacetime,

How to cite this book chapter:

Gillgren, Peter. "Figures of Migration: Intertextuality in Michelangelo's Night." In The Power of the In-Between: Intermediality as a Tool for Aesthetic Analysis and Critical Reflection, edited by Sonya Petersson, Christer Johansson, Magdalena Holdar, and Sara Callahan, 75-97. Stockholm: Stockholm University Press, 2018. DOI: https://doi.org/Io.I6993/baq.d. License: CC-BY. 
where time is short and space is large." It should be added that migration is a central feature not only of culture today but in a much longer European perspective. Looking back over the epochs, migration appears as a continuous phenomenon no less in pre-history, Antiquity, or the Renaissance than today. It is unsurprising, therefore, that migration is a reoccurring theme in the visual arts as well. One of the most well-known themes is the flight of Aeneas, narrating how the hero, his family, and their followers flee from Troy over the Mediterranean Sea, about their settlement in Italy, and ultimately the establishment of the Roman Empire. The story is told, over and over again, in hymns and opera, poetry and literature, as well as sculpture and painting all through the centuries. For a true and thorough understanding, an analysis that goes beyond what is purely media specific seems essential. It should encompass the multimodal reality of historical circumstances and the multimedia assemblages of artistic practice as well as a discussion of the relationship between such aspects and the specific work of art.

The figure of migration is truly a figure of in-betweenness, being on the move from one place to the other and, as a consequence, from one mode of existence to another. Often the image or metaphor of sleep has been used to represent this state of being, in philosophy and poetry as well as in the visual arts. Theories of intermediality may help to clarify these relationships, but in most cases they will fall short of including intersubjective features or cultural contexts in the analysis. The in-betweenness considered in formalist intermedia studies is focused on what is taking place between different media forms. The relationship to social and cultural practices or what is going on between the artist and the public becomes secondary. One way around this restriction isperhaps paradoxically_a return to Kristeva's original concept of intertextuality. ${ }^{2}$

" Mieke Bal, "Intercultural Story-Telling," in Kultur - Wissen - Narration: Perspektiven transdisciplinärer Erzählforschung für die Kulturwissenschaften, ed. Alexandra Strohmaier (Bielefeld: Transcript Verlag, 20I3), 289-306.

2 Julia Kristeva, "Le mot, le dialogue et le roman," in Sémeiōtikē: Recherches pour une sémanalyse (Paris: Seuil, I969), I43-I73; translated in Desire in Language: A Semiotic Approach to Literature and Art, ed. 


\section{Kristeva's Intertextuality}

Following other important semioticians such as Jan Mukařovský and Roland Barthes, Kristeva considered everything a text; not only the visual arts and music but also everyday life and private imagination. ${ }^{3}$ They all belong to the intertextual network of the artistic enterprise that makes art readable. One of her primary examples is the multimodal event of a carnival: Through an intertextual process it may take the artistic form of for example a poem, a painting, or a song. Even more important, though, was Kristeva's opposition to the formalistic schools of semiotics. Using Bakhtin's concept of dialogism as well as Freud, she opposed the analysis of isolated cultural artefacts and insisted on regarding them as parts of a lived experience-on behalf of both artists and public. Associated with this original concept of intertextuality is therefore also the intersubjective or psychological dimension of artistic practices. The thetic drive, the struggle to break loose from patriarchal traditions, is one of the main forces behind every urge to signify, she insisted. On the one hand, all texts are grounded in the chora-the unspoken conditions behind any articulation. On the other hand, a work of art is a struggle with the symbolic Father and with authority. Artistic creations can therefore be understood as efforts to undo and overwrite the predecessors. Paradoxically, the poetic work is an effort to start anew and to get rid of all authoritative interferences, just as much as it is an embracing of those very confining and intertextualizing premises.

It is telling that Kristeva herself gave up the concept of intertextuality only a few years after coining it, finding it watered-out and unproductive when it was used simply as an equivalent to literary influence. ${ }^{4}$ The more precise meaning of the concept has

Leon S. Roudiez, trans. Thomas Gora, Alice Jardine, and Leon S. Roudiez (New York: Columbia University Press, I980). Also published as "Word, Dialogue and Novel," in The Kristeva Reader, ed. Toril Moi (New York: Columbia University Press, I986), 34-6I.

3 Roland Barthes, “De l'oeuvre au texte," Revue d'esthétique 3 (I97I): 225-232; translated as "From Work to Text," in Image-Music-Text, trans. Stephen Heath (London: Fontana, I977), I 5 5-164.

4 Julia Kristeva, La révolution de langage poétique (Paris: Seuil, I974), 57-6I; translated as Revolution in Poetic Language, trans. Margaret Waller (New York: Columbia University Press, I984), 57-6I. 
been debated ever since Kristeva, and in relation to the concept of intermediality it has been understood both as subordinate and as the more profound. 5 In the former case, intertextuality is usually defined as concerned only with the relationship between verbal utterances. This is limiting enough, of course. Even more important is that all further cultural contexts and active subjects are excluded from such systems. Aspects of creativity or reception are missing, and the focus is very much on the formal analysis of fixed artefacts. Below, however, the idea of intertextuality is applied in its original Kristevian meaning, in order to present a close-up reading of Michelangelo's Night in the Medici chapel as a figure of migration. Analysis encompasses intermedia aspects of the work, but the ultimate focus is on the process of semiosis itself. ${ }^{6}$

\section{Michelangelo's Night}

The statue Night was produced under the most difficult of circumstances (Figure I). After completing the Sistine ceiling in triumph in I 5 I 2 followed some years of unfulfilled promises for the artist as he was thrown between the efforts of completing the monument for Julius II's tomb in Rome on behalf of the Della Rovere family and doing works at San Lorenzo in Florence for the Medici. In connection with the Sack of Rome in I 527, he had chosen to return once again from Rome to his native Florence, only to be ensnared by the political and military conflicts of the Italian Wars and the struggles for power within the city walls.

5 The relationship is thoughtfully problematized in Valerie Robillard, "Beyond Definition: A Pragmatic Approach to Intermediality," in Media Borders, Multimodality and Intermediality, ed. Lars Elleström (Basingstoke: Palgrave Macmillan, 2010), I50-162. It is also well presented in Werner Wolf, The Musicalization of Fiction: A Study in the Theory and History of Intermediality (Amsterdam: Rodopi, I999), 35-50. Wolf is on the formalist side of the debate but gives further references also to opponents.

6 This aspect was followed up also in Julia Kristeva, "Le sujet en procès," in Polylogue (Paris: Seuil, I977); translated as "The Subject in Process," in The Tel Quel Reader, eds. Patrick Ffrench and Roland-François Lack (London: Routledge, I998), I33-I78. 


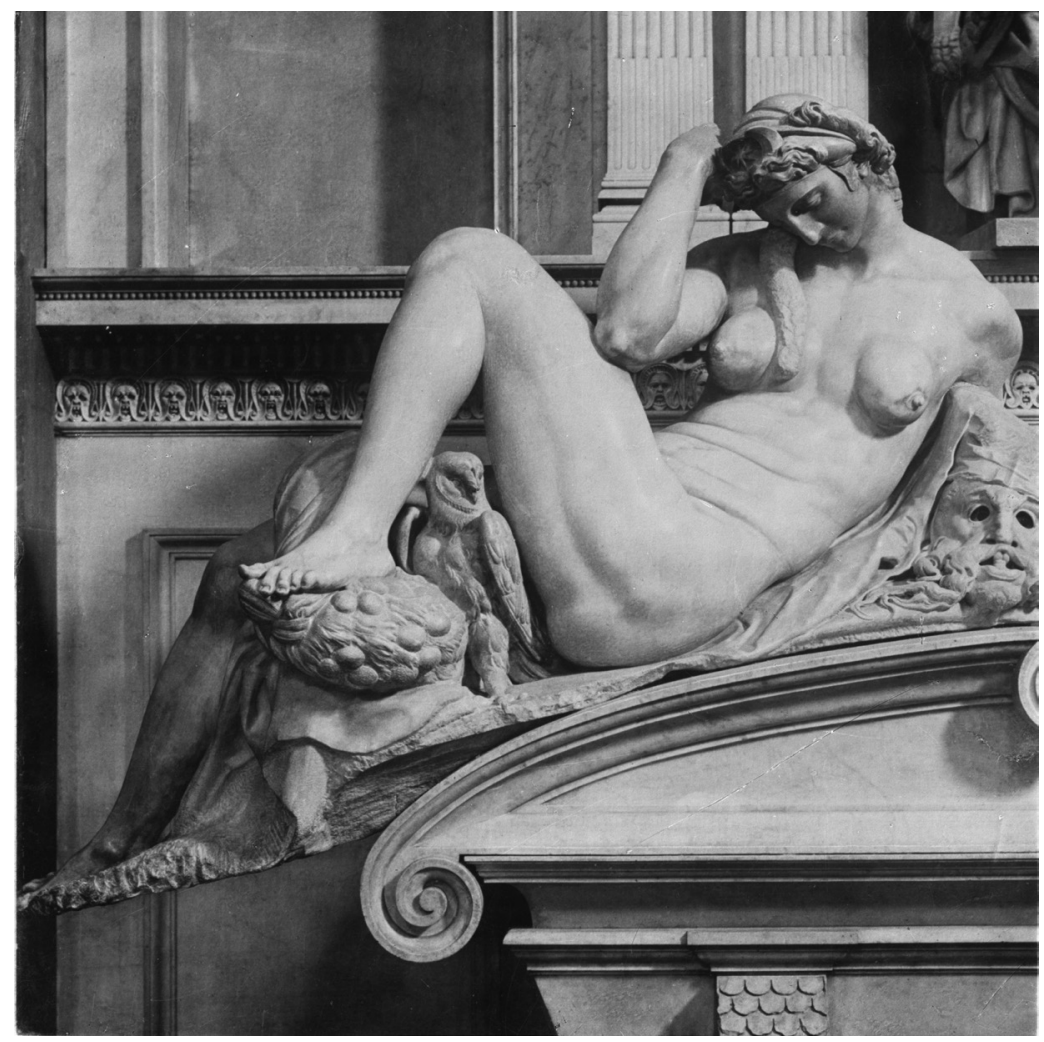

Figure 1. Night. Michelangelo, c. I 530. Marble. The Medici chapel, San Lorenzo, Florence. Reproduction and permission: Bildarchiv Foto Marburg. License: CC-BY-NC-ND.

In the same year, the Medici family was-once again-expelled from Florence, and Michelangelo interrupted his work at San Lorenzo to join the Republican government. His main responsibility was the fortifications of the city, their maintenance, strengthening, and extension. In September I 529, however, the political intrigues become too difficult for him and he decided to flee the city together with two of his friends, Antonio Mini (b. I 506) and the goldsmith Piloto (Giovanni di Baldassarre, c. I 460-I 536). Michelangelo's plan was to go Venice and then, most likely, to France. The three companions were not the only 
ones at flight during these difficult times, though, and Giorgio Vasari (I 5 I I-I 564) writes:

It happened that because of the tumult caused by the wars, and the alliance between the emperor and the Pope, who were besieging Ferrara, wanting to know from those who gave lodgings to travellers the names of all arrivals from day to day; and every day he had brought to him a description of all foreign visitors and where they came from. So when Michelangelo dismounted with his companions, intending to stay in Ferrara without making himself known, his arrival was notified to the Duke $\left[\ldots . .{ }^{7}\right.$

The companions were prevented to leave Ferrara until Michelangelo promised the Duke a painting of his own hand. A painting representing Leda and the Swan was indeed begun by the artist, but it was never delivered. Instead, Michelangelo gave it to his traveling companion Antonio Mini, perhaps as a memorial of their flight. The main figure is close to the figure of Night in the Medici chapel and, unusually, the motif includes the offspring of the seduction, the twins Castor and Pollux. In the Renaissance (as well as later) they were commonly interpreted as representations of Republicanism. The three companions avoid staying at the Duke's castle, insisting on returning to the hostel and to stay with the other travelers and refugees. From Ferrara they went to Venice, but after being "much sought after by various people" and being "strongly urged to return home" Michelangelo did so in December I 529. According to both Vasari and Ascanio Condivi ( I 525-I 574), he feared for his life already at this point, but even more so when, in 530 , the Florentine Republic fell and the Medici family returned to power. He went underground, but was found by the Medici and, ultimately, pardoned under the explicit

7 Giorgio Vasari, Lives of the Painters, Sculptors and Architects II, trans. Gaston du C. de Vere (New York: Everymans Library, I996 [I 568]), 370. "Et a Ferrara condotti, riposandosi, avvenne che per gli sospetti della guerra e per la lega dello imperatore e del papa, ch'erano intorno a Fiorenza, il Duca Alfonso da Este teneva ordini in Ferrara e voleva sapere secretamente da gli osti che alloggiavano, i nomi di tutti coloro che ogni dí alloggiavano, e la lista de' forestieri, di che nazione si fossero, ogni dí si faceva portare. Avvenne dunque che, essendo Michele Agnolo quivi con li suoi scavalcato, fu ciò per questa via noto al duca [...].” 
demand that he would now obediently and without further delay continue work on the tomb sculptures for the Medici chapel. According to Condivi, he set out at once with the work and even though it was now I 5 years since he had handled the tools of a sculptor, he produced all the statues to be seen in the New Sacristy of San Lorenzo in just a few months, including Night, "driven more by fear than by love." 8

\section{Night and the Belvedere Cleopatra}

As for the character of Michelangelo's figure, Vasari's description is both convincing and questionable:

And what can I say of the Night, a statue not only rare but unique? Who has ever seen a work of sculpture of any period, ancient or modern, to compare with this? For in her may be seen not only stillness of one who is sleeping but also the grief and melancholy of one who has lost something great and noble. ${ }^{9}$

Despite Vasari's words, and while it must be admitted that the sculpture is unique, the figure of Night does have some forerunners. The closest one is probably the so-called Cleopatra at the Belvedere court in Rome (Figure 2). She too is a reclining female in an uncomfortable sleep, twisting her torso and folding one arm over the head-as if to suggest difficult dreams and an undefinable anguish. This Antique statue was acquired by Julius II in I 5 I 2 and installed as a fountain in the same year at the Vatican (the very same year that Michelangelo completed the Sistine chapel ceiling). ${ }^{\text {Io }}$ Today the statue is believed to represent Ariadne but during the Renaissance the snake armlet of the left arm made

${ }^{8}$ Ascanio Condivi, Vita di Michelangelo Buonarroti (Pisa, I 823 [I 553 ]), 49; translated as "Life of Michelangelo Buonarroti," in Michelangelo: Life, Letters and Poetry, trans. George Bull (Oxford: Oxford University Press, I987), 45: "più della paura, che dall'amore."

9 Vasari, Lives II, 369. "E che potrò io dire della Notte, statua unica o rara? Chi è quello che abbia per alcun secolo in tale arte veduto mai statue antiche o moderne cosí fatte? Conoscendosi non solo la quiete di chi dorme, ma il dolore e la maninconia di chi perde cosa onorata e grande."

10 Brian Curran, The Egyptian Renaissance: The Afterlife of Ancient Egypt in Early Modern Italy (Chicago: University of Chicago Press, 2007), I67-I77. 


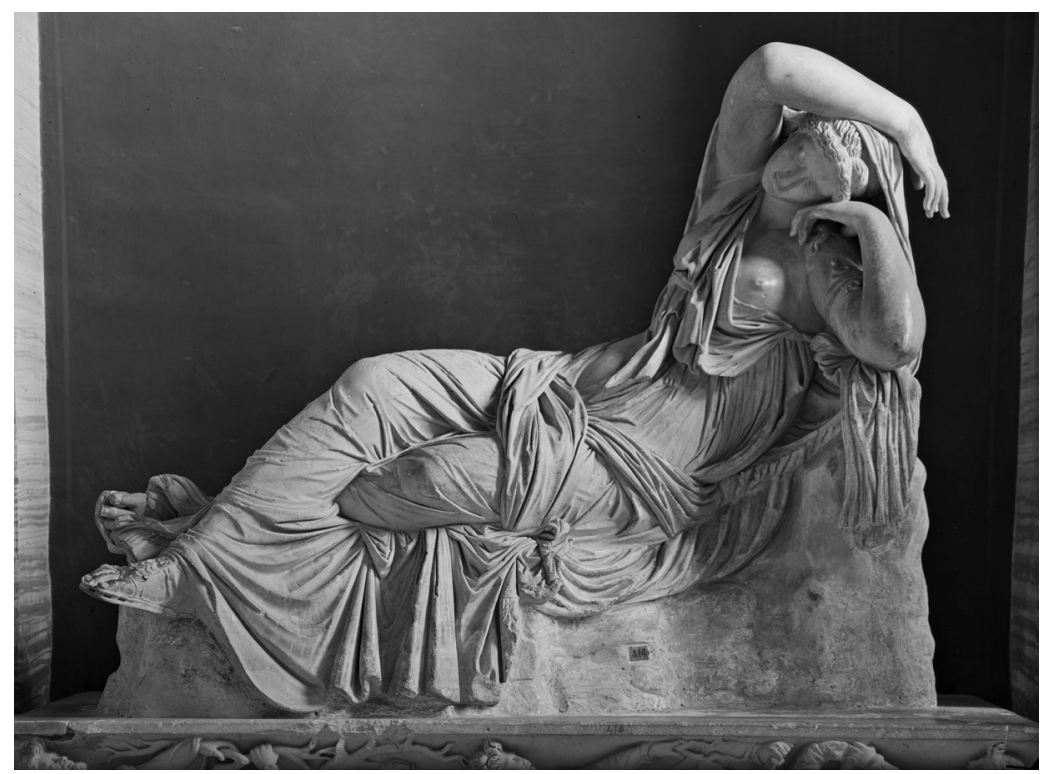

Figure 2. Belvedere Cleopatra. Unknown artist, 2nd century BC. Marble. Vatican Museums, Rome. Reproduction and permission: Bildarchiv Foto Marburg. License: CC-BY-NC-ND.

scholars associate her with the dying Cleopatra. According to Vasari this was one of the classical works-together with the Apollo, the Laocoon, the torso etc. at the Belvedere court-that inspired the bella maniera, the style of the High Renaissance acquired by Leonardo da Vinci, Raphael, and Michelangelo. ${ }^{\text {II }}$ Like Night, Cleopatra belonged to an assembly of sculptures that attracted great attention among artists and poets of the time; they were both parts of courtly and multimodal arenas, where poems were written and exclaimed, music was performed, and artists gathered to exercise the art of drawing. ${ }^{12}$

I Vasari, Lives I, 6I 8.

I2 Sylvie Deswarte-Rosa, "Francisco de Holanda el le Cortile di Belvedere," in Il cortile delle statue: Der Statuenhof del Belvedere im Vatikan (Mainz: von Zabern, I998), 394-395, describes mostly the literary scene and understands the sculpture court as a site for orti letterati. 


\section{Sculpture and Poetry}

For both of these sculptures a number of poems were written. We know more about the ones for Cleopatra. Best known is the poem by Baldassare Castiglione, composed during the pontificate of Leo X (I5I3-I52I). Castiglione describes how the Egyptian Queen is taken prisoner by the Romans and their plans to bring her to Rome in a triumphal procession. Instead, she manages to kill herself with snake poison and escape such a destiny. Among "blazoned inscriptions and enslaved peoples, [is] led through the Capital [instead] the luckless image of a dead woman." '3 Julius II then placed her "among the figures of ancient heroes, and set the stone beneath eternal tears"-referring to her function as a fountain. Tears, Cleopatra insures us, is her only comfort now: "Restore, I beg, that weeping, a weeping which is almost a gift for me, since now heartless fortune has left me nothing else [...]." Other epigrams speak of the figure as sleeping, or rather about the uncertainty as to whether she is dead or still alive. They all seem to go back to an epigram for a sleeping nymph by a well, claimed during the Renaissance to be of Antique origin but today usually attributed to the Roman humanist Gianantonio Campano and dated to around 1470 :

Here I, the Nymph of this place, guardian of the sacred fountain Slumber, while the murmur of gentle water is what I hear.

Whoever touches this hollow marble, take care not to wake me; Whether you have in mind drinking or bathing, do not speak. ${ }^{\mathrm{I}}$

This poetic fascination with sleep goes back at least to Heraclitus' writings, as transmitted to us in fragments by for example St Clement of Alexandria and Plutarch. One of the most wellknown fragments notes that "the waking have one world in common, but the sleeping turn aside each into a world of their own." ${ }^{\text {I5 }}$ Other fragments are even more intriguing and hard to interpret. Somehow, though, they all come down to the fact that we

I3 Curran, Egyptian, I73.

${ }^{14}$ Curran, Egyptian, I75.

Is Heraclitus, "Fragments," in Early Greek Philosophy, trans. John Burnet (London: Black, I9I2), fragment 89; Plutarch, "On Superstition," in 
do not know the dreams and thoughts of the sleeping. We cannot grasp their mode of experience, because dreaming and sleeping is so fundamentally different from knowing the world as when awake. Finally, we do not know, either, if they are dead or alive. And so we ask ourselves: Should we make the effort to awaken them, try make them part of our world again, or are they better off on their own?

The reception and use of the Medici chapel was in many respects similar to the Belvedere complex and Vasari notes that many poems were written for Night as well. ${ }^{16}$ In a few poems that were probably penned down before the sculpture was produced the artist himself celebrates night as a dolce tempo-a pleasant time (Sonnets I02, I03, and I04). ${ }^{17}$ It is a time praised by all with good judgment, he says, for it breaks tiresome thoughts and sweeps them into dark shadows. ${ }^{18}$ The topology of Night is an enclosed and narrow little place-every closed room, every covered site, everything that is circumscribed by materia, is protected by Night. Man is procreated in the night and it is therefore more holy than the day. Continuing on the same theme Michelangelo observes that God created both the sun and the moon and that the latter is closer to man; man is a sublunary being.

Night is also a central deity of Orphic Theogony. ${ }^{19}$ In an alternative version of Biblical cosmology, the Orphists claimed that Chaos gave birth first to Nyx (Night) and then to her brother Erebos. Night then gave birth to Aither and Hemera, also a brother

Moralia II, trans. F. C. Babbitt (Harvard: Loeb Classical Library, I928), 3, I66 C.

${ }^{16}$ Vasari, Lives II, 682-683. These epigrams also relate to a wider tradition from the late fifteenth century of poems dedicated to "sleeping nymphs," often poets connected with humanistic societies gathering in gardens ornamented with fragments of classical sculpture. See Leonard Barkan, "The Beholder's Tale: Ancient Sculpture, Renaissance Narratives," Representations 44 (I993): I33-I66 (with further references).

${ }^{17}$ Michelangelo, The Poetry of Michelangelo, trans. James M. Saslow (New Haven: Yale University Press, I99I).

I8 "tu mozzi e tronchi ogni stancho pensiero, che l'umid' ombra e ogni quiet' appalta."

19 Edgar Wind, Pagan Mysteries in the Renaissance (New York: Norton \& Co., I968 [I958]), I65 ff. 
and a sister. ${ }^{20}$ The same genealogy is given already by Boccaccio in the fourteenth century, but then without the positive connotations that we find for example in Michelangelo. ${ }^{21}$ Traditionally the allegorical figures of the Medici chapel have been identified as the Night with the Day beside her and the Morning together with the Evening on the other sarcophagus. Such an iconography is strangely dull, though, given the otherwise high aspirations of the Medici chapel project. An Orphic and cosmological approach seems more in line with its original overall pretensions. The identity of the allegorical figures is also better in line with the gender of the figures-a brother and a sister on each tomb-as well as with their formal rendering. Night and Darkness are ungraspable and diffuse, while Day and Light, on the other side of the chapel, are more sharply defined (Figures 3 and 4 ). ${ }^{22}$ Such an identification of the figures suggests that the New Sacristy was conceived as an Orphic site, perhaps a select place for chanting and hymns. At one point a relief of Orpheus himself, singing and playing for the animals, was included in the chapel decoration. ${ }^{23}$ It only came to sketches and all such direct Orphic motifs were finally aborted, but the idea of the chapel as a place for praying

${ }_{20}$ William Keith Chambers Guthrie, Orpheus and Greek Religion (Princeton: Princeton University Press, I993 [I952]), 84.

${ }_{21}$ Giovanni Boccaccio, Genealogy of the Pagan Gods I, trans. Jon Solomon (Cambridge: Harvard University Press, 20I I [I370s]), 88-95.

${ }^{22}$ It may well be asked why Vasari (in case the above interpretation is correct) gave us the wrong identity of the figures. He could of course be uninformed, but it is also likely that he wanted to conceal the true identity of the figures and an iconology rivalling Christian cosmology. Writing during the early Counter Reformation, he had every reason to evade cultural ideas that were so much more problematic around I 560 than I 520.

23 The motif of Orpheus and the animals occurs in funerary monuments already in Antique and Early Christian art. It is disputed if this is meant as a figuration of Christ or an image of how hymns, singing, and prayers comforts the deceased and their relatives; Laurence Vieillefon, La figure d'Orphée dans l'Antiquité tardive: Les mutations d'un mythe: Du héros païen au chantre chrétien (Paris: Editions De Boccard, 2003), 95-IO3; Marek Titien Olszewski, "The Orpheus Funerary Mosaic from Jerusalem in the Archeological Museum at Istanbul," in IIth International Colloquium on Ancient Mosaics 2009, ed. Mustafa Sahin (Istanbul: Zero Books, 20I I), 659. 


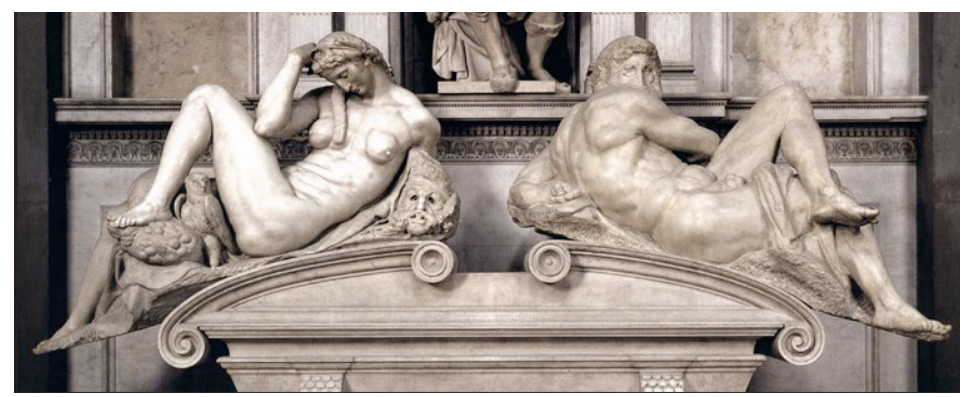

Figure 3. Sculptures for Lorenzo de' Medici's tomb. Michelangelo, c. I 530. Marble. The Medici chapel, San Lorenzo, Florence. Reproduction and permission: Bildarchiv Foto Marburg. License: CC-BY-NC-ND.

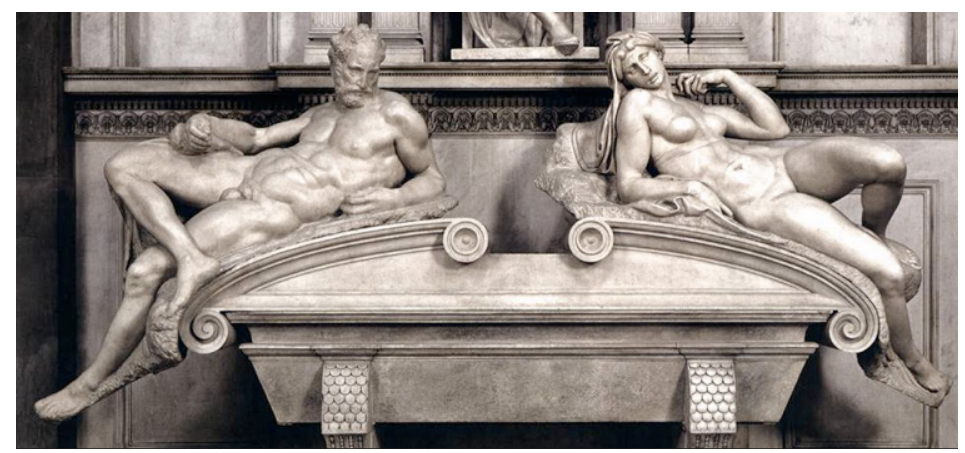

Figure 4. Sculptures for Giuliano de’ Medici’s tomb. Michelangelo, c. I 530. Marble. The Medici chapel, San Lorenzo, Florence. Reproduction and permission: Bildarchiv Foto Marburg. License: CC-BY-NC-ND.

and singing remained. ${ }^{24}$ The Medici chapel received a soundscape of its own, a sonic environment, that included soft whispers just as well as music.

\section{Soundscapes}

In a dialogue published by Donato Giannotti an epigram by Giovanni Strozzi is discussed, where it is said that Michelangelo's Night, seen sleeping, must have been sculptured by an angel-a

${ }^{24}$ Paul Joannides, "A Newly Unveiled Drawing by Michelangelo and the Early Iconography of the Magnifici Tomb," Master Drawings 29:3 (I99I): $255^{-262 .}$ 
play with the artist's name, of course. Since the Nymph is sleeping she must also be alive, and the spectator is asked to awaken her if he does not believe it, in which case she will certainly wake up and speak to him. In response Michelangelo is supposed to have written a short epigram (Poem 247), where Night answers that sleep is dear to her and so is being made out of stone: Not to see and hear during these difficult times is a blessing, so do not wake me up but speak softly. ${ }^{25}$ If these and similar poems were read out loud before Night we do not know, but it is not impossible. The literal content certainly implies so, insisting on the presence of the sculptured figure.

Even though a quiet place, the Medici chapel was never meant to be altogether silent. It was not mute; it had a voice of its own. ${ }^{26}$ With its foundation followed a bull issued in 1532 by pope Clement VII, giving instructions for the eternal prayers that were to be read in the chapel. ${ }^{27}$ The ceremonies probably did not begin until in I 56I, though, since work was still being done in the chapel during the $\mathrm{I} 55$ os. $^{28}$ The bull allowed for four chaplains to be employed. Two priests were to pray together in the chapel, day and night, a voce inelligibile-with intelligible voices. The couple was to be replaced every two hours. Praying together two and two is an unusual arrangement and it was probably meant to strengthen the powerfulness of the invocation. Another consequence was that the two priests could control each other, making sure that

25 "non mi destar, deh, parla basso."

${ }^{26}$ Regarding the differentiation between being silent and mute, see Salomé Voegelin, Listening to Noise and Silence: Towards a Philosophy of Sound Art (New York: Continuum, 2010).

27 The documents were published already in the early nineteenth century but have received little attention among art historians. Domenico Moreni, Delle tre sontuose cappelle Medicee sitate nell'imp. basilica di S. Lorenzo (Florence, I8I3), I52-I56. An attempt at an iconographical interpretation on its basis is done by L. D. Ettlinger, "The Litugical Function of Michelangelo's Medici Chapel," Mitteilungen des Kunsthistorischen Institutes in Florenz 22 (I978): 287-304.

${ }_{28}$ Raphael Rosenberg, Beschreibungen und Nachzeichnungen der Skulpturen Michelangelos: Eine Geschichte der Kunstbetrachtung (Munich: Deutscher Kunstverlag, 2000), I35. The conclusion is drawn by Rosenberg from letters written by Giorgio Vasari during this period. 
none of them escaped their duties. It also meant that the priests were made to pray out loud, so that they could be in synch or relay, giving the ambience a definite and continuous soundscape, not unlike the present one with the soft murmuring of art-loving visitors. The recitations were only interrupted for Mass and the singing of psalms three or four times a day. Some of the psalms may have been especially composed for the site by one of the many composers attached to the Medici court. The two priests would be the third couple of the chapel, so to speak, together with Night and Darkness as well as Day and Light. Like the sculptured figures they represented the continuous coming and going of time, the quiet shifting of positions and the long, long wait for the final coming of Christ. The bull of Clement VII was softened somewhat by Urban VIII in the early seventeenth century but did not lose its impact altogether until the nineteenth century. ${ }^{29}$

The French visitor Nicolas Audebert made a note in his diary of 1576 on the soundscape of the chapel. "It should be mentioned that in the chapel there are always and at all times, by day as well as by night, two priests kneeling in prayer to God for the dead resting in their sepulchers. They are changed every two hours, without any interruption except to sing the high mass or vespers, when all pray together." ${ }^{\circ}$ Though taking note of the praying, Audebert did not refrain from also taking extensive notes on the sculptures, which obviously interested him more. He also took time to produce a small drawing after the most impressive of the statues, the Night. ${ }^{\text {I }}$

The two priests were positioned behind the altar of the Medici chapel, both during prayer and mass, as indicated by another sixteenth-century visitor, Francesco Bocchi:

29 Moreni, Cappelle, I 54-I 56.

30 Published by Rosenberg, Beschreibungen, I49. The full manuscript is in the British Library, Department of Manuscripts. Signature: Landsdowne 720. "Fault remerquer que en ceste chapelle y à tousjours $\&$ et en tout temps soit de jour ou de nuict, deux prestres a genoux à prier Dieu pour les deffuncts qui ont la leur sepulchres eslevez, ce qui se change de deux en deux heures, sans aucune intermission sinon quand lon chante la grande messe ou vespres lors que tous prient ensamble."

35 The drawing is reproduced by Rosenberg, Beschreibungen, I37. 


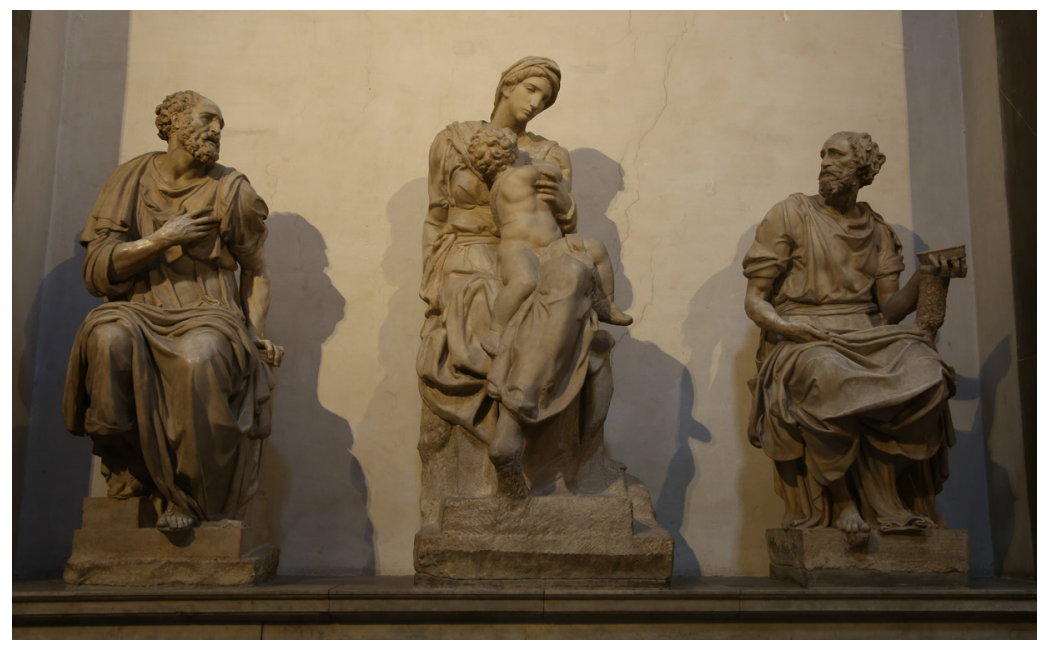

Figure 5. Madonna with Saint Cosmas and Saint Damian. Michelangelo, c. I 530. Marble. The Medici chapel, San Lorenzo, Florence. Photo: Private, Wikimedia Commons. License: CC-BY-SA-3.o. Available at Wikimedia Commons: https://commons.wikimedia.org/wiki/File:Madonna_mit_Kind_ von_Michelangelo_Cappelle_Medicee_Florenz-I.jpg.

For on the altar of this Sacristy, dedicated to the Resurrection, he [Clement VII] wanted-and it is indeed inviolably observed by two priests at every hour and in all seasons-prayers to be said for those souls of the living and the dead of the Medici Family, and for those who are united to them by blood [...] and at least four masses to be said every morning for two hours. ${ }^{32}$

The small exedra joined to the otherwise square chapel plan gives room not only for the two priests but for assistants and a small choir as well (Figure 5). An oddity about the altar is its orientation towards the center of the chapel, rather than towards the wall.

32 "Per che all Altare di questa sagrestia, che ha il titolo della Resurrezione, egli volle, come si offerna innuiolabilmente due sacerdoti ad ogni ora, in ogni tempo facessero orazione per quelle Anima de'vivi, e de morti, che sono della Casa de Medici [...] e che la mattina poscia per due hore si dicessero messe, almeno quattro." Francesco Bocchi, Le belezze della città di Fiorenza (Florence, I677 [I 59I]), 539-540. English translation from The Beauties of the City of Florence: A Guidebook of I59I, trans. Thomas Frangenberg and Robert Williams (London: Harvey Miller, 2006), 254. 


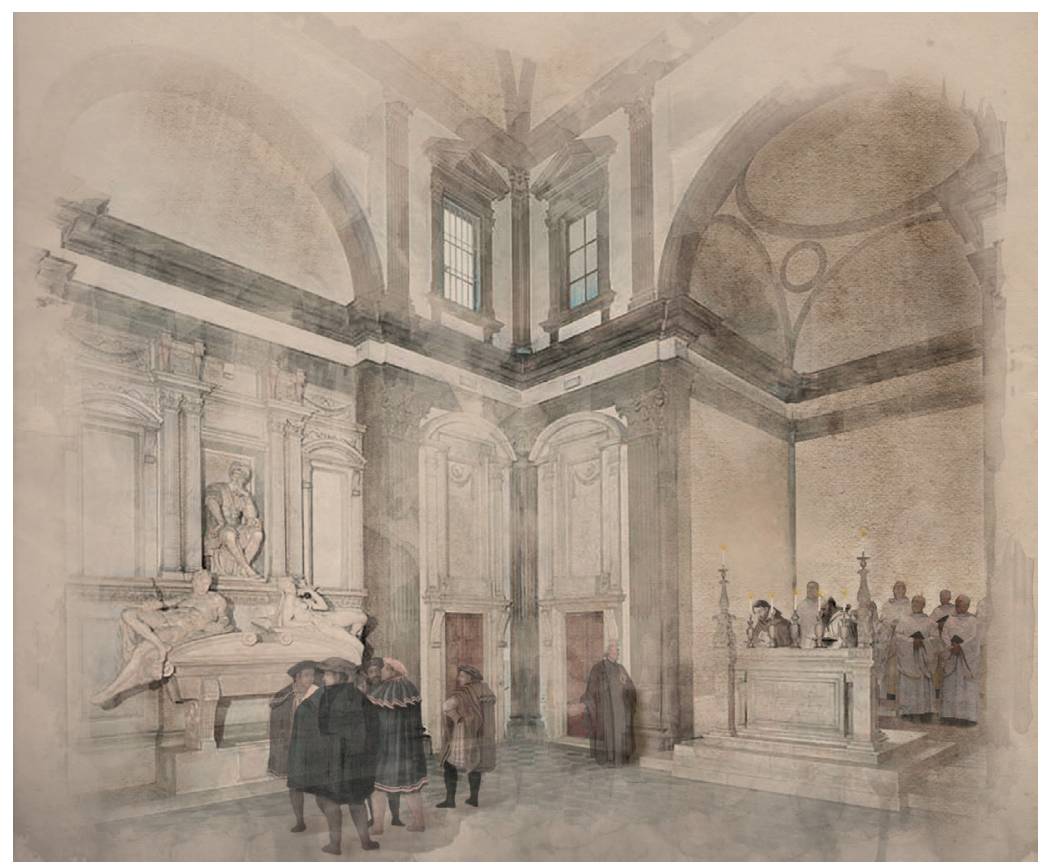

Figure 6. Reconstruction of the Medici chapel during mass. Petter Lönegård, 20I7. Photo and copyright: Petter Lönegård and Peter Gillgren. License: CC-BY-NC-ND.

The general rule was otherwise that the priest should stand by the altar with the congregation behind him. ${ }^{33}$ In the Medici chapel, however, the clergy would be confronting, watching, and directing their attention towards the sculptured tombs and the visitors of the chapel. Likewise, the slowly twisting and turning bodies of the allegorical figures and the captains would be in direct relation to the priests in the choir. It has recently been pointed at the unusualness of this arrangement, suggesting that instead of the placement of a panel above the altar the chapel itself appears as a pictorial installation. ${ }^{34}$

In the chapel we have also, of course, important Christian representations (Figure 6). They differ from the Orphic deities in

${ }_{33}$ Joseph Braun, Der Christliche Altar in seiner geschichtlicher Entwicklung (Munich: Alte Meister Guenther Koch, I924), 407.

34 Alexander Nagel, Medieval Modern: Art Out of Time (London: Thames and Hudson, 2012), 84-90. 
their uprightness and active gesturing. Especially the Madonna is praised by Vasari for its beauty and perfection. Both Saint Cosmas and Saint Damian are probably executed by assistants, but nevertheless they were clearly meant to be more extravert and dynamic than the semi-anonymous and passive pagan gods or allegories. It may well be that in I $52 \mathrm{I}$, when the chapel was first conceived, creating a syncretic ambience of pagan and Christian gods seemed like an excitingly good idea. The Medici fascination for and interest in the Orphic tradition is well-known and documented, not least through the visual arts. ${ }^{35}$ Less than ten years later, when Michelangelo was forced into carving the sculptures, the idea must already have seemed less appealing. When Vasari, finally, wrote about and ultimately completed the installation in the 1550 , even less so. The Christian theme became the dominant one and the presence of the pagan gods is carefully disguised and suppressed. Their identity is uncertain and probably it is meant to be. Instead of an Orphic goddess the figure of Night appears as an anonymous guardian of obscure symbolism with the owl, the mask, and the little clutch of poppies beside her. The transformation gives credence to the old claim that there is an essential affinity between the struggle against the pagan gods and the triumph of allegory. ${ }^{36}$

\section{Pathos Formula}

Loss of home and of identity is the unavoidable fate of both the allegorical figure and the refugee migrant, it seems (Figure 7). There is no more fundamental representation of this than the figure of sleep, functioning as its most efficient pathos formula throughout the ages. ${ }^{37}$ Watching contemporary photographs of slumbering,

35 At the same time as the Medici chapel was begun the statue of Orpheus for the Medici Palace in Florence was commissioned from Baccio Bandinelli; J. Rogers Mariotti, "Selections from a ledger of Cardinal Giovanni de' Medici, I 5 I 2-I 5 I3," Nuovi Studi: Rivista di Arte Antica e Moderna VIVII, 200I-2002 (2003): 103-I 46.

${ }^{6}$ Walter Benjamin, The Origin of German Tragic Drama, trans. John Osborne (London: Verso, I992 [1928]), 220.

37 The concept of pathos formula originates with Any Warburg and is typically defined as "an emotionally charged visual trope"; Colleen 


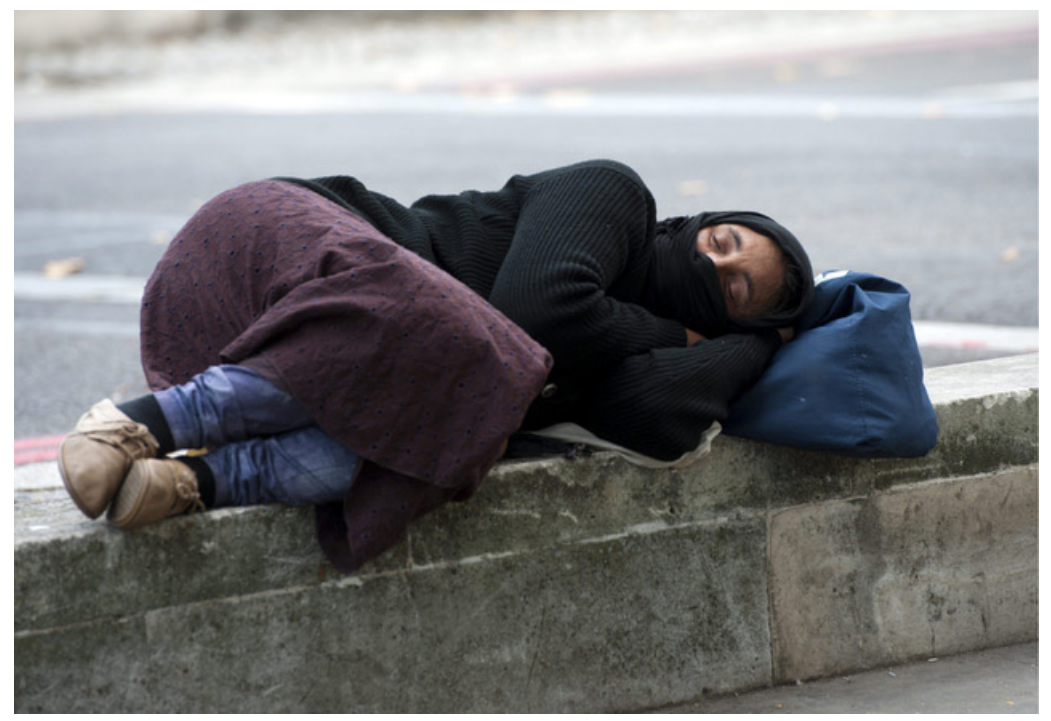

Figure 7. Migrant Sleeping in the Streets of London. Hannah McKay, 2OI4. Photo and copyright: National Picture/Hanna McKay. License: CC-BY-NC-ND.

homeless migrants as they try to cover themselves and to protect their few belongings, the viewer is driven towards asking who they are, where they come from, and what they are experiencing. Their mode of existence remains ungraspable for any outsider and more than often one must remain in silence. Despite its universal nature, the sleeping figure is an ultimate embodiment of estrangement. So familiar, yet so difficult to fathom, it reminds us of our alienation even towards ourselves, when we wake up in confusion after incomprehensible and feverish dreams. At the same time, there is an absolute calmness to sleep, the beauty of simply being within and for oneself; unknowing of all worldly worries and concerns. In sleep, even the ones at flight may find tranquility and joy.

Becker, "Aby Warburg's Pathosformel as a Methodological Paradigm," Journal of Art Historiography 9 (2013): I. 


\section{Conclusions}

Multimedia aspects are crucial for an understanding of Michelangelo's Night. Poetry and hymns celebrating the figure and the chapel must be considered in order to fully understand her. The poetry itself is simple and conventional, and the hymns are unknown but they represent important intermediate links to specific literary and musical traditions-just as much as to the figure itself. The very existence of poetry and sacred soundscape so close to the figure-and the few words that have been noted down-is enough to redefine the concept of Night. It places her in a humanistic or syncretistic context and makes explainable her pose of anguish and evasive gesture. She comes forth as an inbetween existence, as a victim of circumstances, and in a tense and difficult dialogue with historical time and cultural shifts, as they have happened to unfold around her. Such aspects fall beyond conventional ideas about intermediality but are conveniently included in intertextual studies. Even though both traditions are concerned with the interpretation of multimedia or multimodal phenomena, an intertextual analysis is richer and more multifaceted.

Intertextuality, finally, comes in many forms. In our case, there seems to be a direct relationship between Night and the Cleopatra of the Belvedere court, both in media, form and content. Both are celebrities from the East, arriving in Italy in the sixteenth century and praised as mysterious and intriguing figures. There is a certain erotic undertone in how they are celebrated, and there is a sense of amazement and respectfulness as well. It seems that the whole ensemble of "ancient heroes" at the Belvedere court (as Castiglione spoke of them) may have influenced Michelangelo in his work on the Medici chapel. In both cases the statues appear as performative forces at their sites, as foreign elements that have been accidentally brought within an architectural and cultural construct that is not their own-but upon which they have a strong and definite impact. In that sense, the Belvedere court and most of all the so-called Cleopatra served as a prototype for Michelangelo's own work. Equally important are the personal, cultural, or political experiences of artists and commissioners. Michelangelo's 
own experiences of being at flight, as an anonymous overnighter at obscure lodgings, give nerve to the final rendering of this piece of sculpture. Medici considerations of the political wisdom in displaying an interest in Orphic hymns and deities at a public place such as the church of San Lorenzo may have been influential. Such influences are more elusive than the sculptured prototypes, but as productive forces for artistic creativity they must not be underestimated.

Following Kristeva it can be claimed, then, that the artistic work originates in an artistic personality as it is challenged by individual as well as collective experiences and influenced by works of art-in many different media - that the artist is involved with. In this instance, the Cleopatra at the Belvedere courtyard, the planned iconography of the Medici chapel and its prominent soundscape, the experiences of being at flight, negotiations with and threats from the commissioners, changed and discarded plans, Orphic or syncretistic ideas as well as the urge to represent and overcome all these difficulties in an artistic work belong to the intertextual network that makes both conceivable and readable Michelangelo's Night.

\section{References}

Bal, Mieke. "Intercultural Story-Telling." In Kultur - Wissen Narration: Perspektiven transdisciplinärer Erzählforschung für die Kulturwissenschaften, edited by Alexandra Strohmaier, 289-306. Bielefeld: Transcript Verlag, 2013.

Barkan, Leonard. “The Beholder's Tale: Ancient Sculpture, Renaissance Narratives.” Representations 44 (I993): I33-I66.

Barthes, Roland. “De l'oeuvre au texte.” Revue d'esthétique 3 (I97I): $225-232$.

Barthes, Roland. "From Work to Text." In Image-Music-Text. Selection and translation by Stephen Heath, I $55^{-164}$. London: Fontana, I977 [I97I].

Becker, Colleen. "Aby Warburg's Pathosformel as a Methodological Paradigm." Journal of Art Historiography 9 (20I3): I-25. 
Benjamin, Walter. The Origin of German Tragic Drama. Translated by John Osborne. London: Verso, I992 [1928].

Boccaccio, Giovanni. Genealogy of the Pagan Gods. Translated by Jon Solomon. Cambridge: Harvard University Press, 20 I I [I370s].

Bocchi, Francesco. Le belezze della città di Fiorenza. Florence, I 677 [I 59I].

Bocchi, Francesco. The Beauties of the City of Florence: A Guidebook of I 59I. Translated by Thomas Frangenberg and Robert Williams. London: Harvey Miller, 2006 [I 59I].

Braun, Joseph. Der Christliche Altar in seiner geschichtlicher Entwicklung. Munich: Alte Meister Guenther Koch, I924.

Condivi, Ascanio. "Life of Michelangelo Buonarroti.” In Michelangelo: Life, Letters and Poetry. Translated by George Bull, I-73. Oxford: Oxford University Press, 1987 [I 553 ].

Condivi, Ascanio. Vita di Michelangelo Buonarroti. Pisa, I 823 [I 553 ].

Curran, Brian. The Egyptian Renaissance: The Afterlife of Ancient Egypt in Early Modern Italy. Chicago: University of Chicago Press, 2007.

Deswarte-Rosa, Sylvie. "Francisco de Holanda el le Cortile di Belvedere." In Il cortile delle statue: Der Statuenhof del Belvedere im Vatikan, 389-4Io. Mainz: von Zabern, I998.

Ettlinger, L. D. “The Litugical Function of Michelangelo's Medici Chapel." Mitteilungen des Kunsthistorischen Institutes in Florenz 22 (I978): 287-304.

Guthrie, William Keith Chambers. Orpheus and Greek Religion. Princeton: Princeton University Press, I993 [1952].

Heraclitus. "Fragments." In Early Greek Philosophy. Translated by John Burnet. London: Black, I9 I 2.

Joannides, Paul. "A Newly Unveiled Drawing by Michelangelo and the Early Iconography of the Magnifici Tomb." Master Drawings 29:3 (I99I): 255-262.

Kristeva, Julia. Desire in Language: A Semiotic Approach to Literature and Art. Edited by Leon S. Roudiez, translated by Thomas Gora, 
Alice Jardin, and Leon S. Roudiez. New York: Columbia University Press, 1980.

Kristeva, Julia. La révolution du langage poétique. Paris: Seuil, I974.

Kristeva, Julia. "Le mot, le dialogue et le roman." In Sēmeiōtikē: Recherches pour une sémanalyse, I43-I73. Paris: Seuil, I969.

Kristeva, Julia. "Le sujet en procès.” In Polylogue, 55-ı06. Paris: Seuil, I977.

Kristeva, Julia. Revolution in Poetic Language. Translated by Margaret Waller. New York: Columbia University Press, I984 [I974].

Kristeva, Julia. "The Subject in Process.” In The Tel Quel Reader, edited by Patrick Ffrench and Roland-François Lack, I33-I78. London: Routledge, I998 [1977].

Kristeva, Julia. “Word, Dialogue and Novel.” In The Kristeva Reader, edited by Toril Moi, 34-6I. New York: Columbia University Press, I986 [I969].

Mariotti, Rogers. "Selections from a ledger of Cardinal Giovanni de' Medici, I 5 I2-I 5 I3." Nuovi Studi: Rivista di Arte Antica e Moderna VI-VII, 200I-2002 (2003): I03-I46.

Michelangelo Buonarroti. The Poetry of Michelangelo. Translated by James M. Saslow. New Haven: Yale University Press, I99I.

Moreni, Domenico. Delle tre sontuose cappelle Medicee sitate nell'imp. basilica di S. Lorenzo. Florence, I 8 I 3.

Nagel, Alexander. Medieval Modern: Art Out of Time. London: Thames and Hudson, 20I2.

Olszewski, Marek Titien. "The Orpheus Funerary Mosaic from Jerusalem in the Archeological Museum at Istanbul.” In I Ith International Colloquium on Ancient Mosaics 2009, edited by Mustafa Sahin, 655-662. Istanbul: Zero Books, 20I I.

Plutarch. "On Superstition.” In Moralia II. Translated by F. C. Babbitt, 492-55. Harvard: Loeb Classical Library, I928.

Robillard, Valerie. "Beyond Definition: A Pragmatic Approach to Intermediality." In Media Borders, Multimodality and Intermediality, edited by Lars Elleström, I 50-I 62. Basingstoke: Palgrave Macmillan, 2010. 
Rosenberg, Raphael. Beschreibungen und Nachzeichnungen der Skulpturen Michelangelos: Eine Geschichte der Kunstbetrachtung. Munich: Deutscher Kunstverlag, 2000.

Vasari, Giorgio. Le Vite de' più eccellenti pittori, scultori, e architettori. Florence, I 568.

Vasari, Giorgio. Lives of the Painters, Sculptors and Architects I-II. Translated by Gaston du C. de Vere. New York: Everymans Library, I996 [I 568].

Vieillefon, Laurence. La figure d'Orphée dans l'Antiquité tardive: Les mutations d'un mythe: Du héros païen au chantre chrétien. Paris: Editions De Boccard, 2003.

Voegelin, Salomé. Listening to Noise and Silence: Towards a Philosophy of Sound Art. New York: Continuum, 20 Iо.

Wind, Edgar. Pagan Mysteries in the Renaissance. New York: Norton \& Co., I968 [1958].

Wolf, Werner. The Musicalization of Fiction: A Study in the Theory and History of Intermediality. Amsterdam: Rodopi, I999. 
